\title{
Capillaria hepatica-induced septal fibrosis in rats: a contribution to the study of liver fibrogenesis
}

\author{
Contribuição para o estudo da fibrogenesis hepática em ratos infectados com Capillaria \\ hepatica
}

Valter Lucas Chaves Barbosa ${ }^{1}$ and Zilton de Araújo Andrade ${ }^{2}$

\begin{abstract}
Introduction: Septal fibrosis of the liver regularly develops in rats infected with the nematode Capillaria hepatica. Curative treatment of the infection prevents the development of septal fibrosis when intervention occurs up to postinfection day (PID) 15, but not later. The present investigation aimed to demonstrate which parasitic factors are present when the process of septal fibrosis can no longer be prevented by curative treatment. Methods: Wistar rats were infected with 600 embryonated eggs of $C$. hepatica administered by gavage and treated with ivermectin and mebendazole in separate groups at PIDs 10,12, 15, 17 or 20. Rats from each group and their nontreated controls, were killed and examined 40 days after the end of treatment. Results: Findings by PID 15 were compatible with the stage of complete maturation of infection, when worms and eggs were fully developed and a complex host-parasite multifocal necroinflammatory reaction showed greater intensity, but with no signs of septal fibrosis, which appeared from PID 17 onward. Conclusions: Since the worms spontaneously died by PID 15, not only septal fibrosis production, but also its maintenance and further development appeared dependent on the presence of eggs, which were the only parasitic factor remaining thereafter.
\end{abstract}

Key-words: Hepatic fibrosis. Pathogenesis. Capillaria hepatica.

\section{RESUMO}

Introdução: A fibrose septal do fígado se desenvolve regularmente em ratos infectados pelo nematódeo Capillaria hepatica. O tratamento curativo da infecção, feito antes do $15^{\circ}$ dia da infecção, mas não mais tarde, impediu o aparecimento da fibrose septal. O presente trabalho procura verificar qual o estado do parasitismo aos 15 dias da infecção, crucial para patogenia da fibrose septal. Métodos: Ratos foram infectados por via digestiva com 600 ovos embrionados de C. hepatica e tratados com Ivermectina e mebendazol, em grupos separados, aos 10, 12, 15, 17 ou 20 dias após a infecção. $\mathrm{O}$ animal de cada grupo e seus respectivos controles foram mortos e examinados aos 40 dias após o fim do tratamento. Resultados: Os achados aos 15 dias da infecção mostraram a maturação completa da parasitose, com presença de ovos e vermes, circundados por reação necro-inflamatória, mas ainda sem fibrose septal. Daí por diante, a fibrose septal se fez presente. Conclusões: Como os vermes morrem espontaneamente após o $15^{\circ}$ dia da infecção, não apenas a origem, mas o posterior crescimento e a manutenção da fibrose septal dependem da presença dos ovos acumulados no fígado, os quais são os únicos elementos parasitários presentes após o $15^{\circ}$ dia da infecção por C. hepatica no rato.

Palavras-chaves: Fibrose hepática. Patogenia. Capillaria hepatica.

1. Institute of Biology, Federal University of Bahia, Salvador, BA, Brazil. 2. Laboratory of Experimental Pathology, Gonçalo Moniz Research Center, Fundação Oswaldo Cruz, Salvador, BA, Brazil.

Address to: Dr. Zilton de Araújo Andrade. LAPEX/CPqGM/FIOCRUZ. Rua Valdemar Falcão 121, Brotas, 40295-001 Salvador, BA, Brazil.

Phone: 5571 3176-2206

e-mail: zilton@bahia.fiocruz.br

Received in 27/04/2010

Accepted in 27/07/2010

\section{INTRODUCTION}

The experimental model for hepatic septal fibrosis, which invariably develops in rats following infection with the nematode Capillaria hepatica, has already been applied to the study of several aspects of the pathogenesis of hepatic fibrosis ${ }^{1-6}$ since its first description in $1993^{7}$. One advantage of this experimental method lies on its regularity of development, since hepatic fibrosis starts around 16-20 days following infection, establishing portal to portal connections and soon involving the entire liver. The male and female adult worms and their products (larvae and eggs) are lodged within the liver parenchyma, not within portal spaces, which are the sites from where septal fibrosis takes origin ${ }^{8}$. Thus, some type of unknown chemical mediator or mediators seems to be at play in between the focal parenchymal parasite-dependent lesions and the portal spaces. Another curious detail is that, although the infection is self-limited, since the worms die and disintegrate soon after egg-laying, the process of fibrosis continues to present signs of progression thereafter. These are intriguing aspects related to the pathogenesis of fibrosis in this model, which require investigation.

Santos et $\mathrm{al}^{9}$ investigated which of the parasite evolving stage or stages played the key role in pathogenesis of $C$. hepatica-induced septal fibrosis of the rat liver. They were unable to induce systemic septal fibrosis by means of a single parasitic element. Injections of eggs, either into the main portal vein or directly into the liver tissue, resulted in isolated periovular granulomatous reactions, but not septal portal fibrosis. Similarly, the presence of worms alone was not enough to induce septal fibrosis of the liver. However, when the parasite infection was fully developed, curative treatment did not interfere with the progression of septal fibrosis.

Such studies are important because byidentifying the main causative agent of fibrosis, as a parasite factor or factors, this could further stimulate research toward the identification of chemical, cellular or molecular factors involved, as well as the mechanisms involved in the pathogenesis of hepatic 
fibrosis in this particular case. The present study follows this trend and explores a different approach. Since C. hepatica is a self-limited parasitic infection, all the worms spontaneously die and disintegrate a short time after maturity and egg-laying, the present investigation tried to determine what the critical point is and which parasite factors are present, when curative treatment succeeds in preventing or fails to prevent further development of septal fibrosis.

\section{METHODS}

\section{Animals}

A total of 37 female Wistar rats, weighing 160-200g were used. They were maintained in large metallic boxes, in a well ventilated room, with free access to a commercial pellet feed for rats and drinking water, ad libitum.

\section{Infection}

Two rats were separated to serve as noninfected treated controls. All the others were submitted to infection on the same day, with approximately $600 \mathrm{C}$. hepatica embryonated eggs, administered by gavage in $1 \mathrm{ml}$ saline. Of these 35 infected rats, 10 were maintained as infected-untreated controls and 25 were submitted to antihelminthic treatment. Data on egg acquisition and counting and inoculum preparation are described elsewhere ${ }^{10}$.

\section{Treatment}

Two drugs were used for the treatment of all the rats: $1^{\text {a) }}$ ivermectin (Ivotan, Hoechst Roussel Vet. SA), was administered orally in a single dose of $0.2 \mathrm{ml}$ of a solution containing $1 \%$ of the drug; 2a) mebendazol (Medley S.A) was administered by a gastric tube over 5 consecutive days at a daily dose of $5 \mathrm{mg} / \mathrm{kgbw}$. Treatment was well tolerated, with no evident changes in general appearance, activities and the weight of the rats.

\section{Experimental groups}

The rats were divided into 6 groups of 5 animals each. The sole difference among the groups consisted on the time elapsed from infection when treatment took place. The following groups were used: group 1, treated on postinfection day (PID) 10; group 2, treated on PID 12; group 3, treated on PID 15; group 4, treated on PID 17; and group 5, treated on PID 21.

\section{Controls}

Infection controls: two nontreated infected rats were killed together with each treated group. Treatment controls: two noninfected treated rats were killed 10 days after the end of treatment.

\section{Procedures}

All the infected-treated rats were killed 40 days after the end of treatment, together with their two respective nontreated controls. Killing was achieved by severing the abdominal aorta after opening the abdominal wall at midline, under general anesthesia. After gross inspection of the organs, the liver was removed. Small blocks taken from different areas of the liver were immediately fixed in $10 \%$ buffered formalin for at least $24 \mathrm{~h}$. These blocks were submitted to dehydration and paraffin embedding. The $5 \mu$-thin paraffin sections obtained were routinely stained with hematoxilyn and eosin and with Sirius-red for collagen.

Other blocks of liver tissue taken immediately following death were immersed into Tissue-Tek (OCT compound-Miles Inc, USA) and snap frozen in liquid nitrogen. These blocks were kept at $-70^{\circ} \mathrm{C}$ until the moment they were submitted to sectioning in a cryostat at $-201^{\circ} \mathrm{C}$. The $10-15 \mu$ thick cryostat sections obtained were submitted to the indirect immunofluorescence technique to demonstrate laminin. Specific anti-goat anti-laminin serum was kindly donated by Dr. Jean-Alexis Grimaud (Paris, France) and used at 1:100 dilution. The corresponding fluoresceinated anti-goat-gamma-globulin was commercially obtained (Sigma - St. Louis, MO, USA) and was used at $1: 40$ dilution.

\section{Investigation of parasite stages}

At the moment of necropsy, small pieces of liver tissue were placed between two glass slides and smashed to determine microscopic identification of $C$. hepatica stages (larvae, worms and eggs).

\section{RESULTS}

Liver sections from noninfected-treated rats exhibited an essentially normal histology. Evident signs of toxic liver-cell injury, such as fatty change, cytoplasm balloonization, single-cell necrosis and apoptosis, were thoroughly investigated, but with negative results.

The nontreated-infected rats exhibited scattered foci of liver parenchymal inflammation, occasionally located close to disintegrating parasitic structures, from PID 10 onward, when disintegrating larvae could be observed within these foci. By PID 15 , some worms were already differentiating and had become fully developed by PID 17, when numerous eggs were also present around them. From this point on, these focal parenchymal lesions, occasionally presenting focal necrosis associated with signs of larva, egg and worm disintegration, progressively increased in number and size. A mild, diffuse portal mononuclear infiltration and edema were also present.

By PID 17, some portal spaces exhibited a radiated appearance due to the presence of a few short projections toward another neighboring space, though no connections were observed at this time (Figure 1). Some of these projections exhibited the presence of slender collagen fibrils, and signs of vascular proliferation, especially when the basement membrane of small blood vessels were revealed by the immunofluorescent technique for laminin (Figure 2).

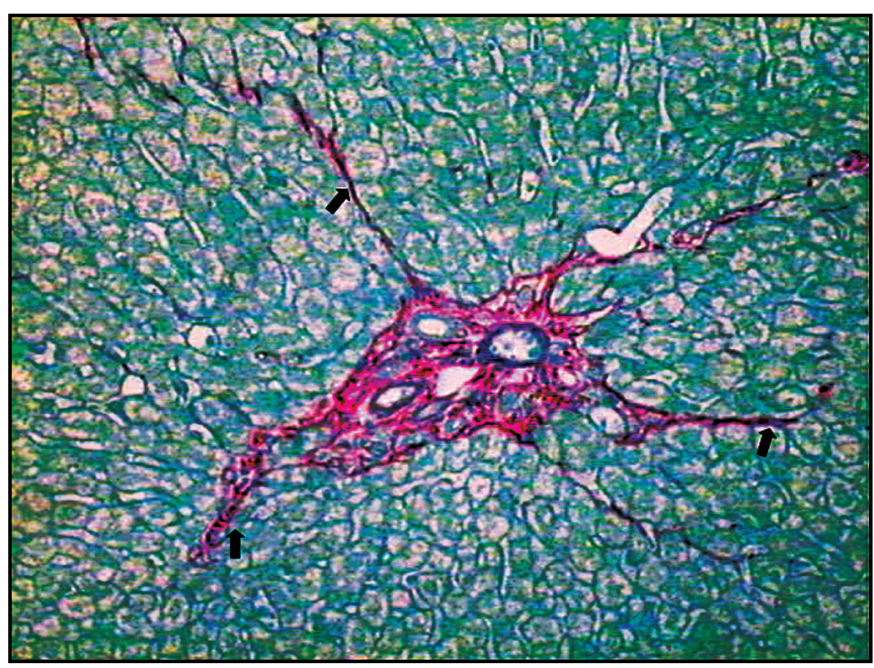

FIGURE 1 - Slender septa can be observed (arrows) sprouting from a portal space 15 days following infection of a rat with Capillaria hepatica. Sirius-red for collagen, $\mathrm{X200.}$ 


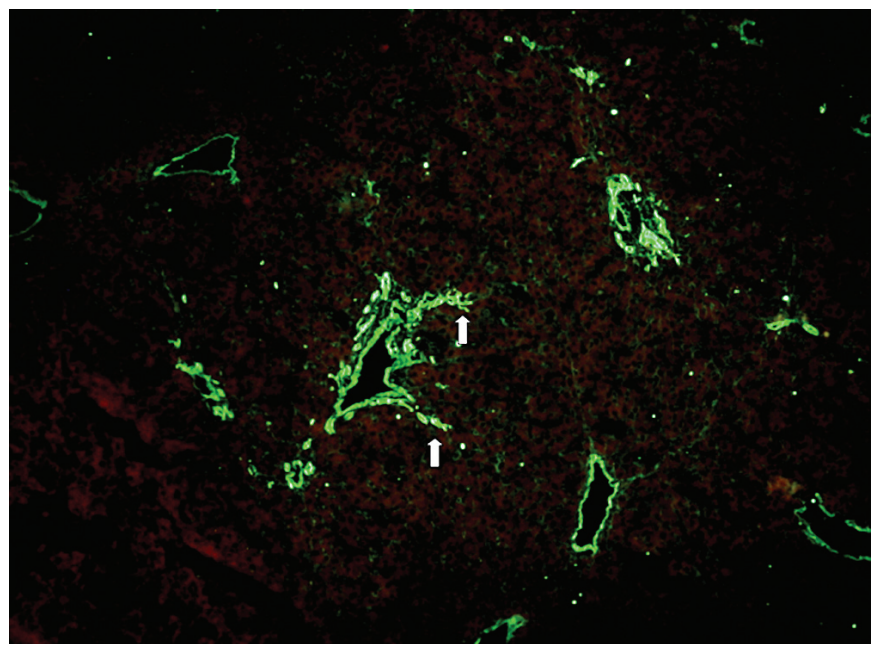

FIGURE 2 - Staining for laminin reveals the presence of blood vessel basement membranes and marks earlier septa developing from portal space. Rat liver at day 17 of Capillaria hepatica infection. Immunofluorescence technique, 100X.

This process of septal fibrosis became evident in specimens examined following day 17 of infection, when connections between portal to portal spaces occurred at several instances (Figure 3).

When examined 40 days after the end of treatment, the infected and treated rats presented the focal parasite-induced lesions of a more or less advanced cicatricial stage. No evidence of septal fibrosis was observed in the livers of rats treated and examined 40 days later, following infections of 10, 12 or 15 day duration.

In contrast, rats treated after PID 17 presented a characteristic picture of septal fibrosis, when examined 40 days after treatment and cure. Septal fibrosis was still more evident in rats treated at PID 21 and examined 40 days later (Figure 3).

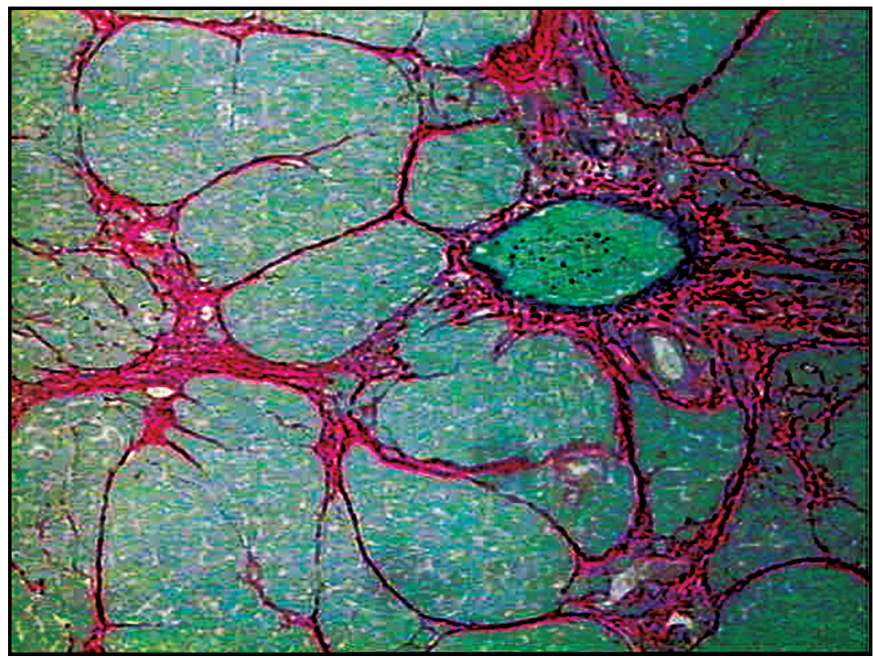

FIGURE 3 - Full developed process of septal fibrosis observed in the liver of a rat 40 days after Ivermectin-Benmidazole treatment of a 17-day old Capillaria hepatica infection. Sirius-red for collagen, 200X.

Smash preparations showed the progressive appearance, differentiation and degradation of larvae, worms and eggs, while the eggs were more stable and became gradually accumulated in focal areas. By PID 10 and 12, only a few developing larvae were identified, but developing worms and a few immature eggs had appeared by PID 17. When examined on day 17 following infection, the livers of both untreated and treated rats revealed the prominent presence of fully developed mature eggs, accumulated around intact and dying adult worms in the center of and encapsulated by chronic granulomatous inflammation. By PID 21, all adult worms were exhibiting signs of disintegration.

\section{DISCUSSION}

Data obtained from the present experiments indicated that septal fibrosis develops in C. hepatica-infected rats by postinfection day 17, when eggs plus living and disintegrating adult worms are clearly visible within foci of chronic granulomatous inflammation scattered within the liver parenchyma. At this time, parasite-related focal inflammatory lesions, which at an earlier stages contained larvae and a few immature worms, now exhibited mature adult live worms with fully developed eggs accumulated around them. No parasite forms were observed inside portal spaces, which are the sites from where septal fibrosis sprouts as fine rays toward the liver parenchyma, eventually connecting portal to portal spaces. Therefore, the present data indicated that the process of septal fibrosis only initiates when C. hepatica has reached full development. From this point on, fibrosis acquires full autonomy and curative treatment of the parasitic infection no longer interferes in its progressive development, at least for the next 4 to 6 months, when septal fibrosis gradually starts regressing ${ }^{4,5}$. Material from our laboratory has revealed that the presence of eggs and septal fibrosis in the liver of rats with a single experimental $C$. hepatica infection can persist for up to two years (data not published).

In conclusion, the present data indicate that the onset of the process of hepatic septal fibrosis in C. hepatica-infected rats requires maturation of the infection, with the presence of adult worms and eggs. The maintenance and further progression of the septal fibrosis process probably depends on the presence of living eggs, which are the only parasitic element present within the liver after the first month of infection. These eggs form large encapsulated collections within the liver parenchyma. Some of them may die and loose their capacity to embryonate when appropriately tested outside the liver. Unpublished data from our service indicates that these eggs are capable of embryonation up to 4-5 months after infection, but no data thereafter are as yet available. It is probable that many encapsulated eggs in the liver are still alive during prolonged infection (capable of embrionation), but others die without disintegrating. Therefore, the present data are in agreement with that reported by Santos et $\mathrm{l}^{9}$, which affirmed that C. hepatica eggs play a key role in the pathogenesis of septal fibrosis of the liver, but the process of initiation seems more complex, initiating only when the infection reaches full maturity.

\section{CONFLICT OF INTEREST}

The authors declare that there is no conflict of interest.

\section{REFERENCES}

1. Andrade RG, Gotardo BM, Assis BCA, Mengel J, Andrade ZA. Immunological tolerance to pig-serum partially inhibits the formation of septal fibrosis of the liver in Capillaria hepatica-infected rats. Mem Inst Oswaldo Cruz 2004; 99:703-707.

2. Gomes AT, Cunha LM, Bastos CG, Medrado BF, Assis BCA, Andrade ZA. Capillaria hepatica in rats: focal parasitic hepatic lesions and septal fibrosis run independent courses. Mem Inst Oswaldo Cruz 2006; 101: 895-898. 
3. Oliveira L, Souza MM, Andrade ZA. Capillaria hepatica-induced hepatic fibrosis in rats. (Paradoxical effect of repeated infections). Rev Soc Bras Med Trop 2004; 37:123-127.

4. Souza MM, Tolentino-Jr M, Assis BCA, Gonzalez ACO, Correia Silva TM, Andrade ZA. Pathogenesis of Septal Fibrosis of the Liver. (An experimental study with a new model). Path Res Pract 2006; 202:883-889.

5. Souza MM, Tolentino-Jr M, Assis BCA, Gonzalez ACO, Silva TMC, Andrade ZA. Significance and fate of septal fibrosis of the liver. Hepatol Res 2006; 35: 31-36.

6. Lemos QT, Magalhães-Santos IF, Andrade ZA. Immunological basis of septal fibrosis of the liver in Capillaria hepatica-infected rats. Braz J Med Biol Res 2003; 36:1201-1207.

7. Ferreira LA, Andrade ZA. Capillaria hepatica: a cause of septal fibrosis of the liver. Mem Inst Oswaldo Cruz 1993; 88:441-447.

8. Andrade ZA, Assis BCA, Souza MM. Capillaria hepatica: papel em patologia humana e potencial como modelo experimental. In: Coura JR, editor. Dinâmica das Doenças Infecciosas e Parasitárias, Rio de Janeiro: GuanabaraKoogan; 2005. p.1121-1132.

9. Santos AB, Tolentino-Jr. M, Andrade ZA. Pathogenesis of hepatic septal fibrosis associated with Capillaria hepatica infection of rats. Rev Soc Bras Med Trop 2001; 34:503-506.

10. Souza MM, Silva LM, Barbosa-Jr A, Oliveira IR, Paraná R, Andrade ZA. Hepatic capillariasis in rats: a new model for testing anti-fibrosis drugs. Braz J Med Biol Res 2000; 33:1329-1334. 